\title{
Aikuisten PISA
}

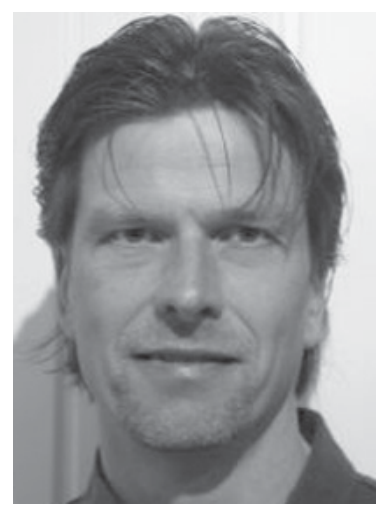

$\mathrm{E}$

uroopan aikuiskoulutusjärjestö (EAEA) tiedotti taannoin kotisivuillaan OECD:ssa valmisteilla olevasta aikuisten PISA-tutkimuksesta. Suunnitelmien mukaan vuonna 2011 toteutettavassa tutkimuksessa vertailutietoa keräätään neljältä keskeiseltä osaamisalueelta. Kyseiset osaamisalueet ovat aikuisten tiedollinen osaaminen (cognitive skills), työpaikkaosaaminen (workplace skills), kirjoitus-, luku- ja laskutaito sekä erityisesti aikuisten valmiudet hyödyntää tieto- ja viestintäteknologiaa. Viimeksi mainitulta osaamisalueelta mitattavat valmiudet kattavat laaja-alaisesti tieto- ja viestintätekniikan teknisen hyödyntämisen, informaation haun, käsittelyn ja sisällön arvioinnin (eli medialukutaidon), uuden tiedon konstruoimisen sekä verkoissa tapahtuvan inhimillisen vuorovaikutuksen. Tiedotteen mukaan mainittuja neljää osaamisaluetta tarkastelemalla kyetään luomaan aiempaa täydellisempi ja vivahderikkaampi kuva inhimillisestä pääomasta. Tulosten oletetaan mahdollistavan aikuiskoulutusjärjestelmien tehokkuuden arvioinnin ja tämän myötä edesauttavan hallituksia aikuiskoulutukseen liittyvien poliittisten linjausten ja päätösten teossa. Testit laaditaan luonnollisesti siten, että ne ovat valideja riippumatta siitä, missä kulttuurissa, millä kielialueella tai missä maassa ne toteutetaan.

Vaikka tiedotteessa välittyvä näkemys aikuisten osaamisesta on hyvin mekaaninen ja epälooginen sekä lupaukset tulosten hyödyntämismahdollisuuksista kovin yksioikoisia, en voi välttyä huolestumasta. Miten meidän aikuisemme pärjäävät vertailussa, eritoten kun nuoremme ovat aiemmissa PISA-tutkimuksissa testauttaneet Suomen maailmankartalle? Mitä jos aikuisemme eivät olekaan maailman parhaita? Tiedämme että pohjoismainen ja suomalainen aikuiskoulutus on laaja-alaista ja osallistuminen aikuiskoulutukseen säännöllisen intensiivistä. Mutta ero tai välimatka muihin maihin pienenee huomattavasti, kun tarkastelun kohteeksi otetaan aikuiskoulutukseen osallistumisen sijaan pelkästään työhön tai ammattiin liittyvään koulutukseen osallistuminen. Ja kun PISA-tutkimuksiin perustuvissa rankinglistoilla operoidaan kokonaispistemäärien keskiarvoilla, saattavat hyvinkin pienet erot keskiarvoissa vaikuttaa sijoitukseen merkittävästi. Se, onko muutaman pisteen erolla mitään käytännön merkitystä, onkin aivan toinen asia.

Suomessahan erot aikuiskoulutukseen osallistumisessa eri koulutustaustan omaavien aikuisten sekä eri ikäryhmien välillä ovat todetusti ja yhä edelleen yllättävän suuret, ehkä hieman tasoittumaan päin. Tasa-arvo näyttää toteutuneen parhaiten sukupuolten välillä. Huomionarvoista on kuitenkin se, että kansainvälisissä vertailuissa koulutustaustan vaikutusta ja eri ikäryhmien välisiä eroja tarkastellaan ainoastaan suhteessa työhön ja ammattiin liittyvään koulutukseen (esimerkiksi Education at a Glance 2007). Vapaan sivistystyön tasaarvoa edistävästä vaikutuksista on näiden vertailujen perusteella vaikea sanoa yksiselitteisesti yhtään mitään. Koska vain osa (10-20\%) vapaan sivistystyön 
tarjoamasta aikuiskoulutuksesta on työhön ja ammattiin liittyvää, saattavat sen hedelmät jäädä ainakin osin huomioimatta aikuisten PISA-vertailussa. Toisaalta, kun kyseessä on "opitun testaaminen” eikä vain pelkkä osallistuminen, saattaa testeissä olla hyötyä vapaassa sivistystyössäkin karttuneista tiedoista ja taidoista.

uonna 2006 toteutetun aikuiskoulutustutkimuksen ennakkotiedot kertovat henkilöstökoulutukseen osallistumisen hiipuneen jonkin verran aiemmasta. Olisiko syynä jo taittunut korkeasuhdanne? Niiden aikana ei aikuisilla aiemminkaan ole ollut yhtä lailla tarvetta eikä aikaa koulutukseen osallistumiseen kuin matalasuhdanteen vallitessa? Mutta myös Aikuiskoulutustutkimuksen 2006 ennakkotiedotuksessa huomio on kiinnittynyt pääosin juuri henkilöstökoulutukseen, eli kuten tulevassa aikuisten PISA-tutkimuksessa, työhön ja ammattiin liittyvään koulutukseen. Näkökulma aikuisten monimuotoiseen toimintaan ja siinä oppimiseen on kovin kapea. Elinikäisen kolmas tuleminen 1990-luvun puolessa välissä enteili näkökulman laajenevan formaaleista ja non-formaaleista konteksteista informaaleihin ja arkipäivän oppimisen spontaaneihin konteksteihin. Nyt on mielestäni pistetty peruutusvaihde päälle.

Mihin on unohtunut konstruktivistinen ja sosiokulttuurinen oppimiskäsitys ja niiden taustalla vaikuttaneet käsitykset tiedon luonteesta? Ovatko ne kaikessa monimuotoisuudessaan sittenkin liian vaativia tapoja hahmottaa ja ymmärtää aikuisten oppimisprosesseja? Aikuisten PISAssa ei olla kiinnostuneita aikuisten oppimisesta ihmisenä kasvamisen edellytyksenä, elämän merkityksen ja mielekkyyden etsimisen ja edistämisen yhtenä ulottuvuutena. Teollisuusyhteiskunnassa työtä kehitettiin mittaamalla ja tehostamalla yksilöiden fyysisiä suorituksia liukuhihnan ääressä. Nyt jälkiteollisessa, postfordistisessa yhteiskunnassa kellokallena toimii OECD ja mittauksen kohteina ovat valtiot sekä niiden koulutusjärjestelmät. Mikään ei ole muuttunut, paitsi tarkastelun taso.

Kapea-alaisuuden ja yksiselitteisyyden vastapainoksi tämänkin numeron artikkelit tarjoavat onneksi monimuotoisempia ja -ulotteisempia näkökulmia ja tarkastelutapoja. Niissä paneudutaan esimerkiksi asiantuntijuuden rakentumiseen kokemuksellisena ilmiönä yhteisöllisissä suhteissa tai aikuisten lukutaidon eri ulottuvuuksiin. Ainakin omalla kohdallani ne pistävät pohtimaan aikuiskasvatustutkimuksen ja aikuiskoulutuspolitiikan suhdetta.

\section{Petri Salo}

psalo@abo.fi 